\title{
Defining social work in Aotearoa: Forty years of pioneering research and teaching at Massey University
}

\author{
Michael Dale, Hannah Mooney, and Kieran O'Donoghue \\ Massey University Press, Auckland, New Zealand, 2017 \\ ISBN 978-0-9941300-9-9, pp. 319, paperback, NZD45.00
}

$\mathrm{O}$ ver forty years ago in 1976, Massey University, Palmerston North accepted an initial intake of students on the first four-year Bachelor of Social Work (BSW) in Aotearoa New Zealand. This readable, informative, and critically reflective text (complete with photographs) celebrates the 40year milestone of the social work programme (the programme) considering this specific history of social work education. The purposes of the research project underpinning the text were to provide an historical record and consider the contribution, influence and impact of the programme to defining social work in Aotearoa New Zealand between 1975 and 2016. It was envisaged that this text would appeal most to alumni from the programme, but it is clear that the content has value for a much wider national, and international, audience.

Commencing with a dedication to Mervyn Hancock and Ephra Garrett (as founding staff of the programme), the text presents the developing programme in six chapters outlining key chronological periods. Each period commences with an overview of the political, economic, social and cultural context linked to developments in social work. This contextualises the story of the evolving programme including how it contributed to social work practice and policy in Aotearoa New Zealand. The final chapter considers the future for both social work and the programme. In addition to the references section, the text contains a useful index of subject areas and a detailed 50-page bibliography highlighting a body of work from Massey social work students, staff and alumni since 1976.
Chapter One introduces the new professional programme for a changing society between 1975-1982. The unique climate of the times is described setting the scene for the developing programme. The programme's aspirations are overviewed including a focus on theory and practice, links to the profession and social services, responsiveness to Aotearoa New Zealand's unique context, growing indigenous constructions of practice, commitment to bicultural practice, and student accessibility via distance learning. Developments in the programme over the first years are outlined including the establishment of student units and postgraduate opportunities.

Chapter Two explores the programme between 1983 and 1992. This period of social and economic transformation, the developing neoliberal ideological approach, economic deregulation, and reduction of the welfare state, culminating in the 1991 "mother of all budgets" (p. 49) provides context. Social policy developments in Māori political consciousness and organisation including an advancing response to race relations, as well as a growing enlightenment regarding issues affecting women, children and disabled persons are asserted. Key reports, legislation and international conventions that reflected the changing times are overviewed. The response of social work education and social work theory is examined, outlining empowerment and ecological systems theories, and the integration of Freire's critical approach, alongside the international influence of empirical practice. The developing identification of the need 
to replace imported practice models with indigenous models such as Te Whare Tapa Whā is identified.

The expansion and development of the programme in a period of reform (1993-2000) is the focus of Chapter Three. The continued scaling back of the state and emergence of managerialism in the social services, priority given to civic responsibility, earned rights and individual autonomy, are outlined. Changes in social work and social services training are identified. Linkages to the expanded activities in the professional association that enhanced visibility, accountability, and focused on tangata whenua social work are connected, including the developing registration project. Programme expansions to Albany and Wellington and additional qualification options are outlined as is disestablishment of the social work student units. Academic staff appointments and changes in this period are linked to key roles in the professional association, government appointments, and major research outputs in social policy, practice research, and Māori scholarship demonstrate the growing impact of the breadth and depth of scholarship.

The period from 2001-2009 is entitled, "Riding the waves of change: reform, regulation and repositioning". This chapter outlines the professional focus and impact of regulation of social work and social work education. Alongside this, the development of the Tangata Whenua Social Workers Association is reported, symbolising to an extent the assertion of rangatiratanga by Māori for Māori. The programme journey is chronicled as achieving synergies between academic focus, research and business efficiency, the demands of the Performance Based Research Funding (PBRF) model, and developing new offerings.

Chapter Five addresses the period from 20102016 and is entitled "Maintaining stability in turbulent times". Political dominance by the New Right, National-led Coalition Government is explained with its emphasis on welfare reform, responsibilisation, and reduction in the state's role in civil society. The programme developments are considered against the backdrop of rapidly changing social, political, and tertiary education environments. An expanding list of achievements, awards, publications, qualifications of staff, students and alumni is outlined, highlighting the major contribution from the programme to social work.

In the final chapter, the future picture for the programme is considered. It is asserted that the programme continues to provide baselines and lead developments in social work education in Aotearoa New Zealand. This chapter returns the reader to the original foundations of the programme. Professor Munford, one of the inaugural students, is asked "How do we support individuals while at the same time challenge the structural conditions that create miserable lives?" (p. 223). While the book highlights many achievements of the programme, it also clearly reflects upon challenges ahead for the profession and social work education. It is wonderful that Merv Hancock's wisdom on the uncertainty of the future completed the text: "Social work can make a contribution to defining the kind of society we live in. Therefore it needs to maintain a level of optimism about itself" (p. 231).

I thoroughly recommend this wellresearched, critical text.

Me hoki whakamuri, kia ahu whakamua kaneke.

In order to improve, evolve, and move forward, we must reflect back on what has been.

Dr Michael Dale is a senior lecturer, Hannah Mooney (Ngāti Raukawa ki te tonga, Te Atiawa, Te Atihaunui a Pāpārangi, Ngā Rauru) is a lecturer, and Kieran O'Donoghue is an associate professor and head of school, all at Massey University's School of Social Work.

Reviewed by Sonya Hunt University of Waikato

(I declare my connection and interest in the text, being one of those inaugural students in 1976.) 